\title{
Police Professionalism in Prevention of Violent Criminal Acts by the Police in Indonesia
}

DOI: https://doi.org/10.47175/rissj.v3i1.380

\begin{tabular}{|c|c|}
\hline $\begin{array}{l}{ }^{1} \text { Magister of Law Brawijaya } \\
\text { University, Indonesia } \\
{ }^{2} \text { Universitas Negeri Medan, } \\
\text { Indonesia } \\
\text { *sitorus.malondo1993@gmail.c } \\
\text { om }\end{array}$ & $\begin{array}{l}\text { ABSTRACT } \\
\text { Savagery is regularly done by police within the examination to } \\
\text { urge a confession the suspect. This behavior has ended up a } \\
\text { propensity that can be referenced from different investigate } \\
\text { comes about, which are caused by need of supervisory } \\
\text { organization examination, an inadequate lawful disobedient, the } \\
\text { assurance of the institution, and the amateurish demeanor of the } \\
\text { police. This circumstance causes no chance to battle for a suspect } \\
\text { his rights and the culprits of savagery blocked off. Polished skill } \\
\text { related with standardized ethical issues into the code of conduct, } \\
\text { and any infringement of ethics code shows a issue within the body } \\
\text { of ethical police. There ought to be a ethical advancement within } \\
\text { the examiner for examination can take put legitimately and } \\
\text { accurately concurring to desires. } \\
\text { KEYWORDS } \\
\text { police violence; investigation; criminal justice system; code of } \\
\text { conduct }\end{array}$ \\
\hline
\end{tabular}

\section{INTRODUCTION}

Security and order are the government's obligations and the basic needs of the community to carry out life activities in society. The existence of security and order that is felt directly by the community will create a level of community welfare as well. On the other hand, the absence of security and order in society will also have an impact on a life that is not prosperous, the sense of being disturbed by their rights makes humans and other humans into wolves who create this chaos.

Security and order are problems that will never end because they are related to private interests and public interests. Therefore, the issue of security and order is a very complex problem, so the realization of security and order must be accompanied by good rules and law enforcement. A systematic study of law enforcement in theory must have elements such as: the existence of legal instruments, law enforcement officers, community members, legal culture or culture, as well as facilities and facilities that support the implementation of the law.. ${ }^{1}$

As explained above, one of the factors that must be considered is law enforcement. In this context, the author raises the legal issue where law enforcement should function to maintain security and order but becomes a factor destroying security and order in society. The law enforcement officers referred to in this paper are the police who have direct functions and duties in society.

The Indonesian National Police (POLRI) is an executive agency tasked with maintaining security throughout the territory of the Republic of Indonesia. POLRI has a role that has the task of realizing security in the State of Indonesia which includes

\footnotetext{
${ }^{1}$ Bagir Manan, 2007, Persepsi masyarakat mengenai Pengadilan dan Peradilan yang baik, Jakarta: Varia Peradilan No.258, Mei, p. 5
} 
maintaining security and order, law enforcement, as well as the implementation of protection, protection, and public services as well as the realization of peace by upholding human rights. The National Police in carrying out these main tasks are carried out starting from National Police officials at the center to regional officials, even members on duty in the field. We can find this in principle in the provisions of Article 2, Article 4, and Article 13 of Law Number 2 of 2002 concerning the Indonesian National Police or in other words the task is based on the applicable law. ${ }^{2}$

Understanding of Polri's organization and personality as previously described. The organizational aspect can be seen from the Polri institution, while the personal aspect can be seen from the Polri members, namely aspects in carrying out their roles, functions, duties and responsibilities. From the explanation above, we can see that the aspects of organizational and personal accountability are different.

If we look at the functions of the police, we can see that in Article 13 of Law Number 2 of 2002 concerning the Indonesian National Police, the order of security and order functions must take precedence, while law enforcement is placed next. ${ }^{3}$ In carrying out their duties, the Police face obstacles from the community, often the image of the police is considered not good. Police is one of the agencies that have difficulty in managing performance to get a good image. Countries that have good democracies, even though their police institutions are also faced with the ineffectiveness of good performance management. The problem faced by the police, as stated by Andras Kadar, is that there is a bad image of the police. The image of the police is a mistake in handling security and order in carrying out their duties. Police professionalism is tested in handling security and order, such as in the investigation stage of cases where the police often commit violent crimes to obtain evidence. ${ }^{4}$

Law Number 2 of 2002 concerning the National Police of the Republic of Indonesia becomes the legal basis in carrying out police duties, which states that for the public interest, the Indonesian National Police apparatus in carrying out their duties and obligations acts according to their authority to judge as stated in Article 18. This is stated in Law Number 8 of 1981 concerning the Criminal Procedure Code (KUHAP), in article 5 paragraph (1) letter a number 4 it is stated that because of their obligations, members of the National Police are authorized to take other actions according to the law for which they are responsible. What is meant by "other actions" in this article are actions carried out by members of the Police or investigators for the purpose of investigation provided that they do not conflict with the laws and regulations and there are reasonable considerations based on coercive circumstances.

The authority to carry out "actions based on self-assessment" as referred to in Law Number 2 of 2002 or "the authority to carry out other acts" as referred to in the Criminal Procedure Code is an act of discretion. Discretionary action is a type of action or power that uses authority based on the initiative of officials. This action is given by law with the intention that officials can carry out their duties properly or in other words carry out their duties for the common good. ${ }^{5}$ As we know that the breadth of the duties and functions of the National Police are not limited to law enforcement, but also include the task of maintaining security and order. and state laws that often conflict with each other. For this

\footnotetext{
${ }^{2}$ Undang-Undang Nomor 2 Tahun 2002 tentang Kepolisian Negara Repubik Indonesia, pasal 13

${ }^{3}$ Staff Pengajar pada Fakultas Ilmu Sosial dan Ilmu Politik Universitas Indonesia. Saat ini menjadi Guru Besar Kriminologi Fisip UI

${ }^{4}$ Kadar, Andras. (ed), 2001. Police in Transition: Essays On the Police Forces in Transition Countries. Budapest: Central University Press

${ }^{5}$ Indriyanti Seno Aji, KORUPSI: Kriminalisasi Kebijakan Aparatur Negara? (Jakarta: 2010) p. 1
} 
reason, there is a discretionary effort made by the Police, this discretionary action must be in accordance with the Good Governance Principles.

The problem of this discretionary action occurs in its application, not always in its application. Police are not always judged as correct or appropriate police actions, errors often occur in the application of this discretion. The application of this discretion theoretically has a negative side, including discriminatory police behavior that causes injustice to individuals handled by the police. Due to the application of wrong discretion, law enforcement is often considered uncertain and even vulnerable to abuse. The negative side of this discretion is if it goes beyond the limits required by the law on the principles of good governance and also occurs because of weak and irregular controls.

In the application of discretion, the police have often practiced in various fields such as law enforcement, handling various cases, as well as in the task of maintaining security and public order. However, oftentimes the application of this discretion does not go well and the police seem deviant. In other words, the application of this discretion has not been fully understood by the police themselves. In this case, it shows how important it is that the supervision of every police personnel must be supervised both by statutory regulations and by supervision carried out by the police agency itself.

Police professionalism seems to be tested in every action. As law enforcers, the police whose functions and duties have been described previously are regulated by law. However, the police also have ties to the existing laws and regulations within their institutions. While the police are also human beings who have the capacity as officers, in every decisionmaking action, of course, there are relationships that are built both in the field and other factors that exist in him.

This factor also affects how police professionals in carrying out tasks, several factors that have enough influence include knowledge of rules, educational backgrounds, assignment periods, work experience, economic conditions or community reactions to their actions. These factors show police quality, so there is no irregularity in the form of violence in the field. Because the police are leading guards in law enforcement, the police must act on order and peace. Relevant morality problems because they are presented paradoxically by the media. Often police officers act outside their authority such as committing violence against the people handled. We know for yourself, violence itself is regulated in law.

Like a case case in North Sumatra, 6 Police Headquarters Mapolsek Percut Sei Mr. has been removed because it has been proven to torture someone named Sarpan. In this case there are violence carried out by police who have produced psychic, material and physical losses. One case of violence carried out by the police seems to be a stone stumbling for the police in carrying out his duties. Cases of violence carried out by the police are cases that occur due to obtaining information and evidence of which legislative regulations are not permitted. ${ }^{6}$

For the police, it is obligatory to know what actions must be taken in the field, whether any actions such as violence are allowed or not in making decisions. The behavior of the police must reflect the existence of legal protection for those they handle. The theory of legal protection itself as put forward by Satjipto Raharjo, legal protection is to supply assurance for human rights that have been harmed by others which assurance is given to the community so that they can appreciate all the rights allowed by law. ${ }^{7}$

\footnotetext{
${ }^{6}$ https://www.suara.com/news/2020/07/14/121752/6-polisi-percut-sei-tuan-terbukti-siksa-sarpan-akhirnyadicopot

${ }^{7}$ Satjipto Raharjo, Ilmu Hukum, Bandung: PT. Citra Aditya Bakti, 2000, p. 53.
} 
Police behavior is often criticized for using violence in carrying out their duties. This violence often occurs when the police are investigating the suspect, often the suspect gets violent with the aim of getting a confession to the suspect. Many studies conducted by the Legal Aid Institute (LBH) found violence against investigations. ${ }^{8}$

With a very broad task and authority delegated to the National Police with each member based on the law. Professionalism is needed for every member of the police force who knows and understands every action he takes so that problem solving occurs in the context of preventing acts of violence committed by his members, so that the negative impact and bad image of the police are not getting worse.

From the background of the problem, the problem is formulated as follows:

1. What are the efforts of the police as law enforcement officers to improve police professionalism?

2. What are the efforts of the police as law enforcement officers to prevent violence in investigations?

This writing aims to be understood as a necessity for police organizations in realizing their duties and functions as guards of security and order and law enforcement and also providing understanding to the public with knowledge of the duties and functions of the police and understanding every police action. which is beyond their jurisdiction.

\section{RESEARCH METHODS}

The type of research used is normative juridical research. Normative legal research, which is a type of legal research by reviewing library materials as a basis for reviewing and conducting searches on legislation and literature related to the problem. ${ }^{9}$ The research approach utilized in this consider could be a statutory approach with the point of checking on statutory directions relating to legitimate issues. ${ }^{10}$

The legal materials used consist of primary, secondary, and tertiary legal materials. Primary legal materials consist of statutory regulations, jurisprudence and court decisions. Secondary legal materials consist of legal materials that provide information related to legal issues in the form of legal journals, books and legal dictionaries. ${ }^{11}$

Tertiary legal materials are used as supporting legal materials that will provide guidance and clarity to primary and secondary legal sources, in the form of dictionaries, encyclopedias, and dictionaries of legal terms. ${ }^{12}$

The technique of collecting legal materials is done by tracing legal materials related to this issue. Then the legal materials obtained in the literature review, legislation and articles will be described and linked in such a way that the writing can be presented in a more systematic form in order to answer the formulated problems. ${ }^{13}$

The technique of analyzing legal materials is carried out using the deductive method, namely drawing conclusions that are universal, general, on the concrete problems faced. In the context of the author's research, the author will first explain and analyze the general concept, namely the concept of justice, after that it will be juxtaposed with real problems.

\footnotetext{
${ }^{8}$ Hamidah Abdurahman, Upaya Perlindungan Hak Asasi Manusia Terhadap Kekerasan Oleh Polisi dalam Penyidikan di Wilayah Tegal, Tesis. Semarang: PPS Ilmu Hukum UNDIP; Anthon F. Susanto, 2004. Wajah Peradilan Kita, Kontruksi Sosial tentang Penyimpangan Mekanisme Kontrol dan Akuntabilitas Peradilan Pidana. Refika Aditama, Bandung;

${ }^{9}$ Peter Mahmud Marzuki, Penelitian Hukum, Kencana, Jakarta, 2005, p. 93

${ }^{10}$ Ibid p. 93

${ }^{11}$ Ibid p. 94

12 Ibid p. 95

${ }^{13}$ Peter Mahmud Marzuki, Op.Cit, p. 21
} 


\section{RESULTS AND DISCUSSION}

\section{Police Efforts to Increase Professionalism}

Professionalism in the Field of Investigation

Investigation is a process of searching and gathering information in connection with a report/complaint about a criminal act with the aim of obtaining complete information, evidence or witnesses so that the next process can be held, namely prosecution or examination. The investigation process is carried out sequentially, namely:

The first stage of the investigation, this stage is the stage of seeking and collecting information regarding the presence or absence of reports/complaints regarding the presence or absence of criminal acts. This investigative authority is given to the police officer assigned to this matter. The basic considerations for conducting an investigation are:

a) Police report

b) Various reports received by investigators

c) Minutes of Investigation at the TKP

d) Minutes of Investigation of the Suspect

This investigation is carried out by investigators as a police work unit in the field of criminal acts which are carried out openly as long as they can produce information and are carried out in secret if during the investigation process it is difficult to obtain. information. This investigation process should follow the following process:

a) Avoid all actions that are contrary to the provisions of the law and applicable laws and regulations.

b) Officers must have expertise in mastering techniques in interviews in the form of observation or supervision and or undercover.

Furthermore, the process to be carried out with the results of the investigation is stated in the form of a report and must be processed properly for the purpose of determining whether a case is a criminal act or not and obtaining clarity to complete the investigation. prosecution interest.

The data processing carried out by the police is very important so it must be processed properly, one way from the police is to process the crime scene processing, namely looking for information, looking for evidence, clues, and the identity of the perpetrator. suspects for the purposes of investigation and search. , retrieval, the collection of evidence with certain methods supported by technical assistance in other areas of expertise. All types of actions that occur at the crime scene are then included in the Minutes of Investigation (BAP).

The investigation process begins with the prosecution process, which means that this process is all legal actions taken against people or objects that are related to the crime in question. This action takes the form of summoning suspects or witnesses and making arrests, detentions, searches and confiscations. This process must be accompanied by the issuance of a summons from the commander or appointed police officer.

The second stage of prosecution, at this stage, explains that every legal act committed against a person or object related to a criminal act is carried out. This stage takes several actions such as:

a. Summoning of suspects and witnesses

b. Arrest, detention, search and seizure.

Every action taken in this stage of prosecution must be in accordance with the law. The authority of the police in the process of summoning suspects and witnesses as well as arrests, detentions, searches and seizures must be accompanied by documents or warrants relating to these actions. This warrant is also issued by the competent police official. 
The third stage of examination is carried out with an examination process which is an activity to obtain information, clarity on the identity of suspects and or witnesses or evidence containing criminal elements. Furthermore, at the stage of completion and submission of files, at this stage it is necessary to pay attention to the following matters:

a. The results of the examination of suspects and witnesses as well as the completeness of the evidence obtained.

b. Elements of evil

c. By law

At this stage of the examination, the police must also pay attention to every inspection process. Like the examination of witnesses, the police must show good character and not be confrontational. During the examination of the suspect, the police informed the suspect's right to obtain legal assistance and did not pressure the suspect. Each stage of the examination is stated in the minutes of examination, all types of actions taken by the suspect and the witness as well as the physical and spiritual health of the suspect and the witness must be in good condition. After that, it must be included in the inspection report that meets the formal and material requirements.

The fourth stage is the completion and submission of files. This stage is the final activity of each investigative process. Things that must be considered in this final stage must be accompanied by evidence and complete examination results from suspects and witnesses, the existence of elements of a criminal act, and also for the sake of law.

Thus, we can see the process that the police must go through in the investigation process, where at each stage of the process there are still stages that must be passed as well. This is what the police must do properly and correctly for the sake of legal certainty. Each of these processes must also be accompanied by cooperation between other institutions outside the police agency, such as from the district court, the prosecutor's office, even to the regional environment, namely the head of the RT/RW.

Police professionalism in this field of investigation must be properly and correctly based. Investigation as a police task is a very complex activity that requires expertise and knowledge as well as responsibility. In addition, the professionalism of the police in the field of investigation can also be hampered due to limited human resources, facilities and infrastructure to conduct investigations, the complexity of inter-institutional relations that are interrelated in the work environment, and the behavior of each member in the investigation. carry out their duties.

This poor assessment of the professionalism of the police is very easy for the public to see because of the many mistakes or excessive powers that the police have exercised. Society demands the police as a place of protection from crime, neutral in their duties, and must carry out their duties under any conditions. This assessment of police professionalism cannot only be judged from the law, but beyond that we must assess the lack of police professionalism which can also be caused by several factors outside the law.

First, the lack of human resources, which means that the police with less resources will hinder the investigation process. These human resources can be measured in terms of the quality and quantity of the police force. In terms of quality, speaking on the basis of education, the problem of education is very clearly felt when the police carry out their duties in terms of law enforcement. This increase in education is also expected to be the answer to the professionalism of the police, with education for each member, all actions in carrying out their duties and functions will run well. In addition, increased education will provide knowledge in the field of attitude in acting in the field. Lack of knowledge in carrying out their duties results in poor police performance, for example a police officer who has just left his education is immediately charged with the task of a sergeant whose 
task must receive basic education. The lack of knowledge of a police officer will hinder the investigation process, especially in terms of evidence that must be processed.

Human resources can also be seen in terms of the quantity of police, in carrying out their duties the police deal directly with the wider community. It is necessary to increase the quantity of police, in terms of quantity where the population of Indonesia is 200 million people, if it is not accompanied by the quantity of police, it will affect the ratio of the population to the number of police. As in Indonesia itself, which has a very large population compared to the number of police officers. This problem will be faced with the burden of the police who in the end are not optimal in carrying out their duties in the process of carrying out their duties, where many cases occur in the community.

Second, the lack of facilities and infrastructure owned by the Police in carrying out their duties. In general, at every institution, infrastructure is needed to support the achievement of organizational goals. Likewise, the police in carrying out their duties in terms of investigations must have simple tools to the most sophisticated tools, especially in the process of searching for evidence that requires sophisticated tools to obtain evidence. The view of the lack of infrastructure owned by the police indirectly affects their professionalism. The much-needed infrastructure will not prevent the police from carrying out their duties as a whole, but the professionalism of the police will continue even though it is not optimal. The existence of a loyal attitude of a police officer who is instilled in every task even though it is based on a lack of facilities and infrastructure, the police will continue to carry out their duties as a form of loyalty to the institution.

Third, the complexity of inter-institutional relationships that are interrelated in the work environment. Police agencies in the law enforcement process are required to cooperate with other agencies such as the prosecutor's office. The relationship between a bad working environment will reflect the poor professionalism of the police because the police are the first line of defense as law enforcers in society. This requires the police and prosecutors to cooperate well in every process where the community demands legal certainty in every legal case experienced by the community.

Fourth is police behavior, police behavior can be said to be professional if the police carry out their obligations in agreement with the laws and directions regarding all police actions. Police behavior in the field of investigation is required to find evidence so that the legal process can run. This police behavior can be related to every action in the investigation process, such as the behavior of the police towards the suspect, the behavior of the police towards witnesses, and the behavior of the police towards the final settlement of the case. The police in each of their actions must be based on good behavior in accordance with the code of ethics or the laws and regulations that bind them. Every action he does to people who have different cases must be good. The behavior of this police officer will be different in each case he experiences, often the police act outside their authority to obtain information or to speed up their duties as a police officer. This is the basis of police behavior as well as an obstacle in increasing police professionalism.

As previously explained, the investigation conducted by the police will run well if the professionalism of the police is there. Likewise, the things that make the investigation not go well and result in a lack of police professionalism are caused by several factors such as human resources, infrastructure, relations between institutions and also the behavior of the police themselves. Seeing this condition, the police must strive for professionalism.

\section{Police Efforts to Prevent Violence in the Field of Investigation}

The professionalism of the police today is demanded more because every implementation of police duties is in direct contact with the public who demand protection and protection 
for the realization of security and order. In addition, the police profession is a specialty that has formal education requirements that can be accounted for. This police profession has strict standard requirements to be able to enter the police membership and also the police organization is also an organization that develops its own theoretical knowledge. ${ }^{14}$

Police professionalism is often hurt by various factors, the first of which can be seen from the economic and political perspective. Economic reasons make someone intend to enter the Police institution in the hope of getting welfare. However, this encourages the practice of corruption and extortion, as well as political factors that can be associated with the election of a police chief who is appointed to build the political dependence of the police on the ruling regime and can be used as a political tool. to carry out his political path. Requires a good leader not only makes the police professionalism problem good, but also must have a high integrative to work well with each other.

Second, in the era of democratic transition, the role and function of the police is increasing, this increase can be seen from the increasing number of new cases so that indirectly the role of the police is also increasing, due to the encouragement of obligations as a law. enforcers This increased role has implications for the internal readiness of the National Police in responding to the strengthening of this authority. Internal readiness is contained in controlling the internal interests of the Police so that they do not conflict with the essence of law enforcement and security. ${ }^{15}$

Third, in carrying out its duties, the Police are faced with obstacles from the community, often the image of the Police is considered less good. Police is one of the agencies that have difficulty in managing performance to get a good image. Countries that have good democracies, even though their police institutions are also faced with the ineffectiveness of good performance management. The problem faced by the police, as stated by Andras Kadar, is that there is a bad image of the police. The image of the police is a mistake in handling security and order in carrying out their duties. Police professionalism is tested in handling security and order, such as in the investigation stage of cases where the police often commit violent crimes to obtain evidence. ${ }^{16}$

As explained above, it can be said that it is a big picture facing the police. The unprofessionalism of the police in economic and political matters where the police in carrying out their duties must be neutral. Seeing this condition, the police must strive for professionalism. To answer this, motivation is needed where a leader gives a sense of responsibility to each member, a leader must set a good example for his members. A leader must also be responsible to every member who makes mistakes, this makes members feel confident and safe in carrying out their duties.

But in this case it is felt to be lacking because we have to look at the ideological side of the transfer of responsibility, a leader who is responsible for the mistakes of his members but on the other hand his subordinates must be loyal to his leader. This makes the police officers unable to carry out their duties freely and will have an impact on their professional attitude.

To overcome this, it is hoped that there will be motivation given by the police to each of its members, such as giving awards to each member who excels by giving an award

\footnotetext{
14 Bibit Samad Irianto, Pemikiran Menuju Polri yang Profeisonal, Mandiri, Berwibawa dan Dicintai Rakyat. Jakarta: Restu Agung, 2006, p. 174

${ }^{15}$ Bayley, David H., 2001. Democratising the Police Abroad: What to Do and How to Do It. Washington: Department of Justice

${ }^{16}$ Kadar, Andras. (ed), 2001. Police in Transition: Essays On the Police Forces in Transition Countries. Budapest: Central University Press
} 
certificate. In addition, with this work motivation, it is hoped that professionalism will become a tangible manifestation so that each member competes to achieve achievements.

Police professionalism can be seen from the increasingly complex tasks and functions of the police. Where on the one hand the police with their duties and functions as servants, protectors and protectors as well as law enforcement.

The obstacle for the police in carrying out their duties is the bad image of the police in the eyes of the public. This is based on the fact that there are still many cases that do not reflect the professionalism of the police, such as violence, extortion, and poor service. Regarding professionalism, according to Jim Burack, he divides it into two concepts, namely:

1. traditional professionalism, which is based on a sense of integrity, honesty, and loyalty to the code of ethics.

2. Modern professionalism, which is based on the police that involves and involves the community in fighting crime.

Modern professionalism here is expected to be the answer to the bad image of the police in the eyes of the public. Community involvement and involvement in crime prevention can be done through the role of the police as the national guard, namely the role in maintaining and maintaining public security. Where the police go directly to the community and provide a sense of security to the community. The police must also mingle with the communities they protect, provide education on self-protection, educate the younger generation about the dangers of drugs and crime, and invite the public as subjects who have the authority and responsibility to manage their own environment independently. safe and orderly way. With this, it is hoped that this can be an answer for the police to avoid a bad image from the public.

Basically professionalism is tested in the law enforcement process, the law gives the police the authority to enforce the law in various pre-emptive ways to repressive methods in the form of examinations and prosecutions. Police professionalism here requires a learning and understanding process, for example in understanding the use of discretion. Police as law enforcement officers, the use of discretion is needed and its use is absolute, so if the police do not fully understand discretion as a form of handling a case. The understanding of this discretion is not fully understood by the police because of the lack of learning about this discretion, this discretion is more known from experience while on duty than formal education or it can be said that there is no special teaching about this discretion, and also wisdom is often only used in function lessons. which in terms of lack of understanding resulted in not realizing a good discretionary function.

The task of the police in the scope of criminal or criminal policy is in applicative policies where repressive measures are often used for the application of the law. This tendency causes the police and their duties to tend to use violence in an effort to overcome or prevent them from carrying out their duties, namely in the investigation process to obtain information from the defendant regarding a criminal act.

Crimes that are increasingly complex and increasingly developed and sophisticated make people feel inferior so that police officers who carry traditional professionalism and modern professionalism make police smart police officers. So the following two concepts must be well combined by the police in order to create good professionalism too. ${ }^{17}$

The complexity of the assignment of the police forces a incredible obligation on its individuals. Law authorization isn't like drawing a straight line prepared with law-making and carried out like a machine, so it looks straightforward and simple (programmed

17 Pudi Rahadi, Hukum Kepolisian: Profesionlisme dan Reformasi Polri. Surabaya: Laksbang Mediatama, 2007, p. 200 
machine demonstrate). The complexity of law requirement is caused by human association within the law requirement prepare. This measurement of human association by Dark is referred to as lawful mobilization, to be specific the method through which the law gets its cases. Without human mobilization or intercession, these cases would not exist, so the law would fair be a dead letter on paper. ${ }^{18}$ The law enables the police to implement the law in a assortment of ways, from pre-emptive to severe implies by constraint and arraignment. The errand of the police inside the scope of correctional criminal arrangement is within the domain of practical arrangement, specifically the domain of the application of criminal law which tends to be oppressive. This propensity causes the errand of the police to be closely related to be repressive. This inclination causes the assignment of the police to be closely related to the utilize of savagery as a way to overcome deterrents within the examination prepare to get confessions or data from litigants with respect to a wrongdoing.

Police activities must continuously contain lawful truth, rather than being utilized as a defense for police activities or making up laws for police activities, this will lead to lawful mistake. In other words, legal elasticity is utilized for the purposes of police activity, within the frame of constrained endeavors to fulfill the goals of political interests, bunch interface, individual or person interface, and other interface. Constrained endeavors on the proper are police activities based on law to restrain the opportunity of somebody who commits a wrongdoing (in specific) that's carried out equitably, truly and accurately, based on legitimate contemplations and legitimate interface. ${ }^{19}$

Examination of suspects by agents within the examination prepare based on different inquire about comes about appears that a culture of savagery among the police still exists, it has indeed ended up a propensity to get confessions from suspects. The police's approach and treatment of suspects is more non-scientific, as on the off chance that it is the social root of the halted design of police examinations. Examination designs based on logical examinations will dodge different shapes of terrorizing, dangers, physical and mental savagery. The examination here is deciphered broadly, counting the design of the Police's dealing with of open mass issues related to the issue of securing human rights. ${ }^{20}$

James Welsh, Amnesty International member from Australia, once stated in a seminar that torture and other ill-treatment are experienced everywhere by criminals during police investigations, including in countries that uphold human rights. Torture is used as a means of obtaining confessions. ${ }^{21}$

P. Kooijmans, as the Special Rapporteur for Komnas HAM, criticized the work pattern of the National Police which specifically examines allegations of human rights violations in Indonesia related to the Criminal Procedure Code. Kooijmans gave an assessment and concluded that the police had full specialist over a 20-day detainment, in this way permitting for human rights infringement to happen. On the off chance that there's no uncommon institution that can suit complaints of mishandle and viciousness that regularly happens at the beginning arrange of the examination, both at the handling arrange within the field and at the examination organize. ${ }^{22}$

\footnotetext{
${ }^{18}$ Donald Black dalam Satjipto Rahardjo, 2002, op.cit, p. 175. Baca juga A. Reni Widyastuti, "Penegakan Hukum: Mengubah Strategi dari Supremasi Hukum ke Mobilisasi Hukum untuk Mewujudkan Kesejahteraan dan Keadilan”, Jurnal Hukum Pro Justitia Vol. 26 No. 3 Juni 2008, FH Universitas Parahyangan Bandung, pp. 240-247

${ }^{19}$ S.A. Soehardi, 2008, Polisi dan Profesi, PD. PP Polri Jawa Tengah, Semarang, p. 26.

${ }^{20}$ Indriyanto Seno Adji, 2009. Humanisme dan Pembaruan Penegakan Hukum. Kompas Gramedia, Jakarta, p. $36 \& 59$.

${ }^{21}$ Indriyanti Seno Adji, 2009, op.cit, p. 60

${ }^{22} \mathrm{Ibid}$, p. 61. Bandingkan dengan pendapat Gunarto yang justru menganggap KUHAP (yang didalamnya memuat batas waktu penahanan) sebagai titik tolah perlindungan HAM, meski sebatas pada tersangka.
} 
In reality, expectant states of mind and activities have been expressed through universal disobedient. Luhut Pangaribuan said that the rule joined to the tradition is non-derogable human rights, meaning that viciousness or torment in any shape (physical or mental) does not have an state of mind of prohibition so that each endeavor to torment or torment is without special case and beneath any circumstances. (in a state of war, residential political insecurity) isn't justified and could be a genuine infringement of criminal law. ${ }^{23}$

The violence carried out by investigators in the investigation leads to the morality of the police. Ethical quality alludes to human behavior as a human being that's related with one's activities, so that ethical standards are norms used to measure the right and wrong of human actions as humans. The science that talks about ethical quality or around people as distant as profound quality is concerned or which examines ethical behavior is ethics. ${ }^{24}$

The code of ethics for proficient holders is summarized within the Code of Ethics which contains moral substance, both expressive, regulating and meta-ethical ethics. ${ }^{25}$ So the code of ethics is related to certain callings so that each calling has its claim code of ethics. In any case, not all employments can be considered as callings that are entitled and commendable of having their possess code of ethics. There are three criteria that can be utilized to degree whether a work could be a calling or not. To begin with, the calling is carried out on the premise of a tall level of mastery and can subsequently as it were be entered by those who have experienced profoundly progressed specialized instruction and preparing. Moment, the calling requests that the mastery it employments continuously creates consistently and is created routinely in agreement with wants of the community who inquire to be served by a calling that aces these proficient aptitudes, or in other words, there are certain guidelines of skill had. required to be aced. Third, the calling continuously creates teach and educate to control so that proficient abilities are utilized dependably, beginning with true and caring benefit, and all of this is often thought to be for the advantage of the individuals. ${ }^{26}$

A profession could be a ethical community that has shared standards and values. They moreover frame a bound together calling since of the same educational foundation and together have ability that's closed to others. Hence, the profession gets to be a gather that has its own qualities and so has uncommon obligations. Since it incorporates a imposing business model on certain aptitudes, there's continuously a threat of the calling closing itself off from outsiders and becoming an inaccessible group. ${ }^{27}$

The code of ethics can offset the negative viewpoints of the calling and with the presence of a code of morals open believe in a calling can be fortified, since each client has

Marcus Priyo Gunar- to, "Perlindungan Hak Asasi Manusia di Indonesia dalam Dinamika Global", Jurnal Mimbar Hukum Vol. 19 No. 2 Juni 2007, FH UGM Yogyakarta, p. 265.

${ }^{23}$ Instrumen tersebut antara lain Crime Prevention and Cri- minal Justice (pencegahan kejahatan dan peradilan pidana), yang berkaitan dengan treatment, punishment, and extra legal executions yaitu dengan dikemukakannya Dec- laration against Torture and Other Cruel, Inhuman or Degrading Treatment or Punishment sebagai Option Pro- tocol dari The International Covenant on Civil and Political Right (ICCPR) yang disahkan Majelis Umum PBB, 9 Desember 1975. Deklarasi ini ditingkatkan menjadi Convention against Torture and Other Cruel Inhuman or Degrading Treatment or Punishment yang disetuju Majelis Umum PBB, 10 Desember 1984 di mana Indonesia turut menandatangani 23 Oktober 1985. Ibid, pp. 199-200. Baca juga Indriyanto Seno Adji, "Catatan Tentang Penga- dilan HAM dan Masalahnya", Majalah Hukum Pro Justitia Tahun XIX No. 1 Januari 2001, FH Unpar Bandung, pp. 31- 38

${ }^{24}$ K. Bertens, op.cit, hlm. 15; Franz Magnis-Suseno, 1987, Etika Dasar: Masalah-masalah Pokok Filsafat Moral, Yogyakarta: Kanisius, p. 18

${ }^{25}$ Lihat penjelasan tentang jenis-jenis etika ini pada K. Bertens, ibid, pp. 15-22.

${ }^{26}$ Soetandyo Wignyosoebroto, 2003, Hukum: Paradigma, Metode dan Dinamika Masalahnya, Jakarta: ELSAM dan Hu- MA, pp. 316-317

${ }^{27}$ K. Bertens, op.cit, p. 280. 
certainty that their interface will be ensured. The code of morals is like a compass that appears the ethical course of a calling and at the same time ensures the ethical quality of the calling within the eyes of the open. In arrange for the code of morals to operate appropriately, the code of morals must be a self-regulation of the calling. By making a code of morals, the calling itself will decide in dark and white its eagerly to realize ethical values that are considered fundamental, which are never forced from exterior. Another necessity is that its usage is checked persistently. ${ }^{28}$

Police as a profession have a code of ethics as a guide to behavior in carrying out their duties. The police code of ethics is formulated in three categories, namely service ethics, institutional ethics, and state ethics. Regarding the theme of this paper, only ethical points related to service and institutional ethics will be mentioned. Some of the ethics included in service ethics are formulated as follows, not causing suffering due to abuse of authority and intentionally causing anxiety, doubt and dependence on parties related to the case; be respectful to anyone and do not show arrogance/arrogance because of power; speak harsh and angry words; violates and or deviates from the task procedure; degrading human dignity. One of the ethics formulated in institutional ethics is that every member of the National Police in carrying out official duties must not exceed the limits of their authority and must convey their responsibilities to their direct superiors.

Based on the description above, it can be seen that acts of violence committed by the police/investigators in the investigation are not justified by police ethics, and can even be criminal acts. Disclosure of abusive and obscene words accompanied by physical torture is a violation of the code of ethics that must not be carried out in an effort to seek information from a suspect. This is where it appears that the professionalism of investigators in investigations needs to be re-examined, or rebuilt so that this behavior does not recur and becomes a habit.

There are several reasons for behavior that investigators allow and do not provide legal protection for the suspect. First, efforts to stop violence through the judicial process are not regulated by law. Pretrial as a way to stop the investigation process (Article 77 of the Criminal Procedure Code) is only intended to assess the validity of an arrest, detention, termination of investigation and termination of prosecution. Suspects usually use other means to obtain rights confiscated by the police in an investigation by making a different confession or revoking the confession given at the time of the investigation which has been included in the Minutes of Examination at trial. ${ }^{29}$ However, this step also often fails, because judges are $99 \%$ more confident in the BAP made by the police. The state, through the police, which is supposed to provide protection to suspects, failed to carry out its mission.

Second, it relates to the requirements for the effectiveness of the implementation of the code of ethics, namely supervision. In this case, there is no institution or person supervising the exam. For this reason, it is necessary to rethink the existence of commissioner judges whose authority exceeds pretrial. For this reason, what needs to be changed is the statutory regulations, so that the existence of the commissioner of judges gains legitimacy. ${ }^{30}$

\footnotetext{
${ }^{28}$ Ibid, pp. 280-282.

${ }^{29}$ Bahkan, eksplisitas penjelasan Pasal 52 KUHAP menya- takan bahwa supaya pemeriksaan dapat mencapai hasil yang tidak menyimpang daripada yang sebenarnya, maka tersangka atau terdakwa harus dijauhkan dari rasa takut. Oleh karena itu, wajib dicegah adanya paksaan atau teka- nan terhadap tersangka atau terdakwa. Seorang saksi yang mencabut keterangan di persidangannya dijamin oleh undang-undang, sepanjang alasan pencabutan itu dapat diterima oleh pengadilan. Indriyanto Seno Adji, 2009, op.cit, p. 37

${ }^{30}$ Harapan untuk memiliki lembaga hakim komisaris saat ini sedang diupayakan melalui RUU KUHAP yang sampai saat ini belum jelas keberlanjutannya. Oleh Adji dikatakan bahwa Rechter Commissaris (Hakim
} 
Third, regarding the support of the Police Institution for investigators who commit acts of violence during investigations, the question of whether any action has been taken by the institution against police officers who have committed acts of violence during the investigation has remained unanswered. If you look at the role that must be played by the police, then this is an irony which unfortunately is seen as efficient by the police.

The role of the police is to form an identity, namely as arbitrary law enforcement officers, namely police who are aware of their role as guards, protectors of community and community values, and are quick to use violence and are very authoritarian. All that is owned by the police at this time has not been able to make a professional police officer. There are even public doubts about the performance that will be realized by the police in the future. ${ }^{31}$

Police problems are not only technical mastery (hard skills), but also soft skills, one of which is communication. This was acknowledged by the National Police Headquarter (MABEL POLRI) $^{32}$ who argue that police have certain characteristics that hinder communication because of their stressful and conflicting working conditions. These situations make the police develop negative characters or tend to communicate, such as prejudice, excessive suspicion, bullying style, aggressiveness, urge to show off, disrespect, pretentious power, and lack of empathy.

The best way to describe a police officer is to describe him as "moral with violence" or "violence with a moral core." Police work is based on this image and therefore there is a lot of ambivalence in it. According to Baker and Carter, this kind of police conduct and conduct is very dangerous, because police practice is seen as a yardstick by which to judge the sanctity of government, pressure and loyalty to constitutional guarantees and in many cases, police integrity is a window through which we can open. use it to judge the honesty of all government actions. ${ }^{33}$

\section{CONCLUSION}

There are two conclusions that can be given based on the problems, results and discussion of the research as mentioned above. First, the police are still using violence to obtain confessions or information from suspects during investigations. The forms of violence carried out by investigators are physical, psychological, and legal violence. The state failed to provide legal protection to the suspect because there were no regulations that the suspect could use to fight for rights that had been violated by investigators; the performance of the supervisory agency in the investigation has not run optimally; and the existence of protection from the police institution against investigators who commit violence.

Second, all of the facts mentioned above show that the police in conducting investigations are not yet professional, so that making the police professional becomes a difficult task for the police institution. Efforts to build or create a professional police force must start from the beginning, namely at the selection and education level, even this effort

\footnotetext{
Komisaris) dapat melakukan investigating judge, selain examinating judge, terhadap pelaksanaan upaya paksa yang menyimpang dari polisi (atau aparatur penegak hukum lainnya), baik soal penangkapan, penahanan, penggeledahan, maupun penyitaan dan pola penanganan kerusuhan public. Ibid, p. 62.

31 Suwarni, 2009, Perilaku Polisi, Studi atas Budaya Organisasi dan Pola Komunikasi. Nusa Media, Bandung, p. 10. Lihat dan bandingkan dengan Harkristuti Harkrisnowo, 2003, Mendorong Kinerja POLRI Melalui Pendekatan Sistem Manajemen Terpadu. PTIK Press, Jakarta, p. 10.

${ }^{32}$ Mabes Polri, 2006. Perpolisian Masyarakat. Mabes Polri, Jakarta, pp. 110-111

${ }^{33}$ Satjipto Rahardjo dan Anton Tabah, 1993, Polisi, Pelaku dan Pemikir. Gramedia Pustaka Utama, Jakarta, pp. 187-188.
} 
must be continuously nurtured because the implementation of police duties has a high standard of expertise and ethical standards.

\section{REFERENCES}

Bagir, Manan. (2007). Persepsi masyarakat mengenai Pengadilan dan Peradilan yang baik, Jakarta: Varia Peradilan No. 258 Mei

Undang-Undang Nomor 2 Tahun 2002 tentang Kepolisian Negara Repubik Indonesia, pasal 13

Kadar, Andras. (ed). (2001). Police in Transition: Essays On the Police Forces in Transition Countries. Budapest: Central University Press

Indriyanti Seno Aji. (2010). KORUPSI: Kriminalisasi Kebijakan Aparatur Negara, Jakarta

Satjipto, Raharjo. (2000). Ilmu Hukum, Bandung: PT. Citra Aditya Bakti

Hamidah, Abdurahman. (2004). Upaya Perlindungan Hak Asasi Manusia Terhadap Kekerasan Oleh Polisi dalam Penyidikan di Wilayah Tegal, Tesis. Semarang: PPS Ilmu Hukum UNDIP; Anthon F. Susanto. Wajah Peradilan Kita, Kontruksi Sosial tentang Penyimpangan Mekanisme Kontrol dan Akuntabilitas Peradilan Pidana. Refika Aditama, Bandung

Bibit, Samad Irianto. (2006). Pemikiran Menuju Polri yang Profeisonal, Mandiri, Berwibawa dan Dicintai Rakyat. Jakarta: Restu Agung, 2006

Ivkovic, Sanja Kuntjak. (2005). Fallen Blue Knight: Controlling Police Corruption. New York: Oxford University Press

Bayley, David H. (2001). Democratising the Police Abroad: What to Do and How to Do It. Washington: Department of Justice

Kadar, Andras. (ed). (2001). Police in Transition: Essays On the Police Forces in Transition Countries. Budapest: Central University Press

Pudi, Rahadi. (2007). Hukum Kepolisian: Profesionlisme dan Reformasi Polri. Surabaya: Laksbang Mediatama

Reni Widyastuti. (2008). Penegakan Hukum: Mengubah Strategi dari Supremasi Hukum ke Mobilisasi Hu- kum untuk Mewujudkan Kesejahteraan dan Keadilan", Jurnal Hukum Pro Justitia Vol. 26 No. 3 FH Universitas Parahyangan Bandung

S.A. Soehardi. (2008). Polisi dan Profesi, PD. PP Polri Jawa Tengah, Semarang

Indriyanto Seno Adji. (2009). Humanisme dan Pembaruan Penegakan Hukum. Kompas Gramedia, Jakarta

Marcus Priyo Gunar. (2007). Perlindungan Hak Asasi Manusia di Indonesia dalam Dinamika Global", Jurnal Mimbar Hukum Vol. 19 No. 2 FH UGM Yogyakarta, p. 265.

W. Poespoprodjo. (1988). Filsafat Moral, Kesusilaan dalam Teori dan Praktik, Bandung: Remadja Karya. (2005). 102; K. Bertens, Etika, Jakarta: Gramedia Pustaka Utama

Peter Villiers. (1999). Better Police Ethics, A Practical Guide, Jakarta: Cipta Manunggal, p. 48-50; Franz Magniz-Suseno, 1994, Etika Politik Prinsip-prinsip Moral Dasar Kenegaraan Modern, Jakarta: Gramedia Pustaka Utama

Franz Magnis-Suseno. (1987). Etika Dasar: Masalah-masalah Pokok Filsafat Moral, Yogyakarta: Kanisius

Soetandyo Wignyosoebroto. (2003). Hukum: Paradigma, Me- tode dan Dinamika Masalahnya, Jakarta: ELSAM dan Hu-MA

Suwarni. (2009). Perilaku Polisi, Studi atas Budaya Organisasi dan Pola Komunikasi. Nusa Media, Bandung, p. 10. Lihat dan bandingkan dengan Harkristuti Harkrisnowo, 2003, Mendorong Kinerja POLRI Melalui Pendekatan Sis- tem Manajemen Terpadu. PTIK Press, Jakarta, p. 10. Mabes Polri, 2006. Perpolisian Masyarakat. Mabes Polri, Jakarta

JoAnne Brewster, Michael Stoloff, and Nicole Sanders. (2005). Police Academies in Changing the Attitudes, Beliefs, and Behavior of Citizen Participation, American Journal of Criminal Justice,

Satjipto Rahardjo dan Anton Tabah. (1993). Polisi, Pelaku dan Pemikir. Gramedia Pustaka Utama, Jakarta 